\title{
Impact of Job Stress on Job Satisfaction among Air Traffic Controllers of Civil Aviation Authority: An Empirical Study from Pakistan
}

\author{
Muhammad Iqbal \\ Doctoral Research Fellow, Economics Department, University of Karachi, Pakistan \\ iqbalarfeen@gmail.com Tel: +92 3022008835
}

Muhammad Adnan Waseem

Lecturer Deptt. of Management Sciences, COMSATS institute of IT Abbottabad, Pakistan adnanw24@yahoo.com Tel: +92 3013061092

Accepted: March 29, 2012 Published: May 27, 2012

Doi:10.5296/ijhrs.v2i2.1854 URL: http://dx.doi.org/10.5296/ijhrs.v2i2.1854

\begin{abstract}
Purpose - The aim of the study is to investigate the impact of job stress on job satisfaction of employees and also to find out the drivers for the job stress, which contribute to create job stress which ultimately negatively affect job satisfaction.

Design/methodology/approach - The study is mainly based on review of the existing literature and collection of data through an adopted questionnaire survey, conducted from the selected sample of Air Traffic Controllers of Pakistan Civil Aviation Authority. A total of 134 questionnaires were distributed among the sample which is selected using the technique of cluster sampling. 122 respondents returned the questionnaire, which are utilized for the analysis purpose.
\end{abstract}

Findings - The results of the current study indicate that there is a negative relationship between job stress and job satisfaction. Those air traffic controllers who had high level of job stress had low job satisfaction.

Research limitations - This research paper is based on a specific case of Air Traffic Controllers of Pakistan Civil Aviation Authority. So the results are applicable specifically to Air Traffic Controllers of Pakistan Civil Aviation Authority or other fields in the same industry. A quantitative methodology is used to investigate the problem. Future research can investigate the problem by using a mix of quantitative and qualitative research methodology.

Practical implications - The practical implications of the paper include implementation of the results provided by researcher to decrease the employees' level of stress and increase job 
satisfaction level.

Originality/value - The study is conducted first time in the field specifically highlighting the stress issue. It can be a base for the future research in this area.

Keywords - Job Stress, Job Satisfaction, Air Traffic Controllers

\section{Paper type - Research Paper}

\section{Introduction}

Work is a central part of almost everyone's life. Work and the workplace emphasizes many issues related to organizational psychology including job satisfaction, quality of work life, human factors, work conditions, performance appraisal, motivation and leadership, and the physical and mental health of workers. Smother (1994) argued that perceived satisfaction on the job is reflected by the needs of sense of fulfillment and expectation for the job to be interesting, challenging and personally satisfying. As per Side (2002) the job satisfaction is an achievement indicator in career developmental tasks.

Sexton \& Helmreich (2000) and Sexton, Thomas \& Helmreich, (2000) concluded that stress is recognized as a significant factor affecting performance in aviation. Every job, paid or unpaid, has moments of stress. Responsibility without authorities, boring meetings, power struggles, too much (or too little) to do, office gossip, and personality clashes - the workplace is fertile breeding ground for stress. Workplace stress continued to shoot up dramatically in the civil aviation organizations across the world.

Air traffic controllers are stressed by job insecurities in the face of downsizing and restructuring within the organization. Different researchers provided their views about stress e.g. Melhuish (1981) found that stress is the unhealthy response of the individual at a particular time to the wide variety of factors affecting him at the time, Bergh and Theron (2000) argued that stress is a condition which develops when the demands made on people exceed their adaptive (coping) abilities; and Fisher (1994) stated that stress is perceived whenever there is low personal control or jurisdiction over the physical, psychological or social environment.

The main focus of this study is to identify the stress drivers and then there ultimate effect on the air traffic controllers' job satisfaction. Although in the previous studies, relationship between job stress and job satisfaction has been anlysed e.g. (Ahsan et al., 2009) but in the current study authors have tried to analyse this relation in different scenario with different sample size. Another motive for the current study is that, there is no study conducted in Pakistan especially in Civil Aviation Authority by taking into consideration the above mentioned variables. Because employees of Pakistan Civil Aviation Authority are facing much problem of job dissatisfaction which is to be identified that what is/are the motives behind this dissatisfaction. So ultimately it can be stated that this study will be very much helpful to identify the reasons for job dissatisfaction especially in the Air Traffic Control Department of Civil Aviation. Apart from the above, another objective for the current study is to analyze the stress drivers in any given situation which is to classify six variables that are performance pressure, role ambiguity, home work interface, work load and relationship with 
others, which contribute to air traffic controllers' job stress and later on to estimate their direct and indirect effects on job satisfaction.

In coming lines of the current study, relevant literature is reviewed, theoretical framework and hypotheses are developed, sample is drawn from the identified population and collected data is analysed by using SPSS. Later on results are drawn and discussed. In the last portion of the study, limitations and the practical implications of the study are discussed.

\section{Literature Review}

Coleman (1976) concluded that a modern time is the age of anxiety and stress. The stress itself will be affected by number of stressors. Beehr and Newman (1978) defined stress as a situation which force a person to deviate from normal functioning due to the change (i.e. disrupt or enhance) in his/her psychological and/or physiological condition, such that the person is forced to deviate from normal functioning. Schnieder et al (2003) found that employee attitudes concerning satisfaction with pay, satisfaction with security, and overall job satisfaction were correlated with financial (return on assets) and market performance (earning per share). Schneider et al. (2003) also found reciprocal relationship between satisfaction with pay and financial performance; that is, both influenced each other over time. Employees are stressed out because they are layoffs, instability, uncertainty, changes in roles and responsibilities, and increased workload (Sharratt, 2003). Many employees agree one of the most common problems in the workplace today is stress. Stress causes loss of productivity, loss of efficiency, increased employee absenteeism, and many other problems (Marilyn, 2003).

Stress is not necessarily a negative phenomenon; it is usually connected with human-environment interactions. Stress at work can be generated by Tasks Demand (work overload or work under-load), Role Demands (role ambiguity and role conflict), and Interpersonal Demands.

McGinty (2007) concluded that the stress in the workplace reduces productivity, increases management pressures, and makes people ill in many ways. Evidence shows that the problem is increasing. Stress levels rocketed in 2005 - all around the world, whether economic activity was picking up or slowing down (Amble, 2006).

There are several variables which can create job stress for an employee. In the current study, author has taken into consideration performance pressure (Scott, 1966), role ambiguity (Fisher and Gitelson, 1983), home work interface (Alexandros-Stamatios et al., 2003), work load (Wilkes, Beale, Hall, Rees, Watts \& Denne, 1998) and relationship with others (Sauter, Murphy \& Hurrell, 1992) as the drivers for job stress for an employee.

\section{$2.1 \quad$ Performance Pressure}

Selye (1956) emphasizes that stress is a necessary part of life and that it does not always involve negative consequences for the organism involved. In fact, at certain moderate levels, stress can actually improve individual performance. There is substantial research supporting the concept of good stress. Yerkes and Dodson (1908) were the first to stumble upon the inverted-U relationship between stress and performance. Research since Yerkes and Dodson has supported the inverted-U relationship between stress and performance. Scott (1966) found that individual performance increases with stress and resulting arousal to an optimal 
point and then decreases as stress and stimulation increase beyond this optimum. Furthermore, Srivastava and Krishana (1991) found evidence that an inverted-U relationship does exist for job performance in the industrial context. Selye (1975) and McGrath (1976) also suggested an inverted-U relationship between stress and performance. Sanders (1983) and Gaillard and Steyvers (1989) argued that performance is optimal when arousal is at moderate levels. When arousal is either too high or too low, performance declines.

\subsection{Role Ambiguity}

Role ambiguity is another aspect that affects job stress in the workplace. Rizzo, et al (1970); Van Sell et al (1981); and Fisher and Gitelson (1983) concluded that role ambiguity is indeed negatively correlated with job satisfaction, job involvement, performance, tension, propensity to leave the job and job performance variables. Role ambiguity has been described by Kahn et al (1964) as the single or multiple roles that confront the role incumbent, which may not be clearly articulated (communicated) in terms of behaviors (the role activities or tasks/priorities) or performance levels (the criteria that the role incumbent will be judged by). Naylor et al. (1980) state that role ambiguity exists when focal persons, (role incumbents), are uncertain about the product to evaluation contingencies and are aware of their own uncertainty about them. Breaugh and Colihan (1994) have further refined the definition of role ambiguity to be job ambiguity and indicate that job ambiguity possesses three distinct aspects: work methods, scheduling, and performance criteria. Jackson and Schuler (1985) and Muchinsky (1997) found that role ambiguity lead to such negative outcomes as reduces confidence, a sense of hopelessness, anxiety, and depression. Alexandros-Stamatios et al. (2003) says that management role of an organization is one of the aspects that affect work-related stress among workers. Kahn and Quinn (1970) referred role stress as anything about an organizational role that produces adverse consequences for the individual.

\subsection{Home Work Interface}

Sarantakos (1996) argued that family and work are inter-related and interdependent to the extent that experiences in one area affect the quality of life in the other. According to Alexandros-Stamatios et al. (2003) home-work interface can be known as the overlap between work and home; the two way relationship involves the source of stress at work affecting home life and vice versa affects of seafaring on home life, demands from work at home, no support from home, absent of stability in home life. Home-work interface is important for the workers to reduce the level of work-related stress. According to Lasky (1995) demands associated with family and finances can be a major source of extra organizational stress that can complicate, or even precipitate, work-place stress. Russo and Vitaliano (1995) argued that the occurrence of stressors in the workplace either immediately following a period of chronic stress at home, or in conjunction with other major life stressors, is likely to have a marked impact on outcome.

\subsection{Workload}

With increased complexity, controllers use more economical control procedures to regulate their workload. Several studies have highlighted the deleterious consequences of high workloads or work overload. According to Wilkes et al. (1998) work overloads and time constraints were significant contributors to work stress among community nurses. Workload stress can be defined as reluctance to come to work and a feeling of constant pressure 
accompanied by the general physiological, psychological, and behavioral stress symptoms. Hendy et al. (2001) pointed out that time pressure is the underlying stressor that determines operator performance, error production, and judgment of workload. The time pressure and task demand are the operant conditions that influence operators subjectively and objectively.

\section{$2.5 \quad$ Relationship With Others}

Workplace relationships are unique interpersonal relationships with important implications for the individuals in those relationships and the organizations in which the relationships exist and develop. The quality of the relationships has important consequences for employee experiences, including employee information experiences. Both the quality of interpersonal relationships at work as well as the lack of social support from others in the workplace is potential sources of job-related strain. Sauter at el (1992) concluded that poor relations with colleagues, supervisors and subordinates at work have been identified as important risk factors for stress-related problems. Cox and Griffiths (1995) argued that individuals are relatively isolated and receive little support from colleagues, supervisors, friends or family.

After reviewing the drivers for the job stress, author has analysd the relationship between job stress and job satisfaction. Studies have proved a very vital negative relationship between job stress and job satisfaction (Marilyn, 2003 and Homburg \& Stock, 2004).

\subsection{Link between Job Stress and Job Satisfaction}

Several studies have tried to determine the link between stress and job satisfaction (Williams \& Wong, 1999; and Williams, Pitre \& Zainuba, 2000). Job satisfaction and job stress are the two hot focuses in human resource management researches. According to Stamps and Piedmonte (1986) job satisfaction has been found significant relationship with job stress. Cooper, et al (1989) identified four job stressors that were predictive of job dissatisfaction. In other study, Vinokur-Kaplan (1991) stated that organization factors such as workload and working condition were negatively related with job satisfaction. Fletcher and Payne (1980) identified that a lack of satisfaction can be a source of stress, while high satisfaction can alleviate the effects of stress. This study reveals that, both of job stress and job satisfaction were found to be interrelated.

Previous studies have reported that job satisfaction influenced a variety of employee's affective states, such as mood that have an impact on a person's behaviour, for example, performance and organizational citizenship (Williams \& Wong, 1999; and Williams et al., 2000). Studies have reported that employee participation in decision making is positively associated with employee motivation, job satisfaction, organizational commitment, and to a lesser extent, job performance (Cotton et al. 1988; and Ganster, 1989). Loveman (1998) identifies that satisfied employees are more committed to serving customers, which have been supported by Silvestro (2000) and Yoon \& Suh (2003).

The study of Landsbergis (1988) showed that high levels of work stress are associated with low levels of job satisfaction. Moreover, Cummins (1990) have emphasized that job stressors are predictive of job dissatisfaction and greater propensity to leave the organization. Babjide and Akintay (2011) indicate that the pressure emanated from the job has considerably influenced the perceived level of job satisfaction. Study of Igharia and Greenhaus (1992) also reveals that job stress affects job satisfaction and career satisfaction negatively. Koslowsky, et al. (995) concluded that if a definite link exists between two variables, it could be possible for 
employees to provide intervention in order to increase the level of one of the variables in hope that the intervention will improve other variable as well. In this study, author tried to examine the interrelation between job stress and job satisfaction among air traffic controllers.

\subsection{Theoretical Framework and Hypotheses}

There exist two major objective to conduct this study, first one is to classify some significant variables which contribute to air traffic controllers' job stress and secondly to analyze their relation with job satisfaction by keeping in view the scenario of Pakistan Civil Aviation Authority. So resultantly this research will provide a practical implication for the further insight as to what extend can the selected variables influence in the job satisfaction among air traffic controllers of Pakistan Civil Aviation Authority. Two main constructs are included in the proposed research model below encompassing job stress and job satisfaction. The definitions of these variables are listed as follows:

(a) According to Beehr (1995) job stress is a situation in which some characteristics of the work situation are thought to cause poor psychological or physical health, or to cause risk factors making poor health more likely.

(b) Hackman and Oldham (1975) argued that job satisfaction includes general elements and specific elements: the whole perception of job pleasure is considered as general elements; job security, pay, co-worker, supervision and personal growth and development are considered as specific elements.

Keeping in view the reviewed literature of different variables, their relationships are illustrated in figure 1. All five job stressor affect job stress and job stress negatively affect job satisfaction.

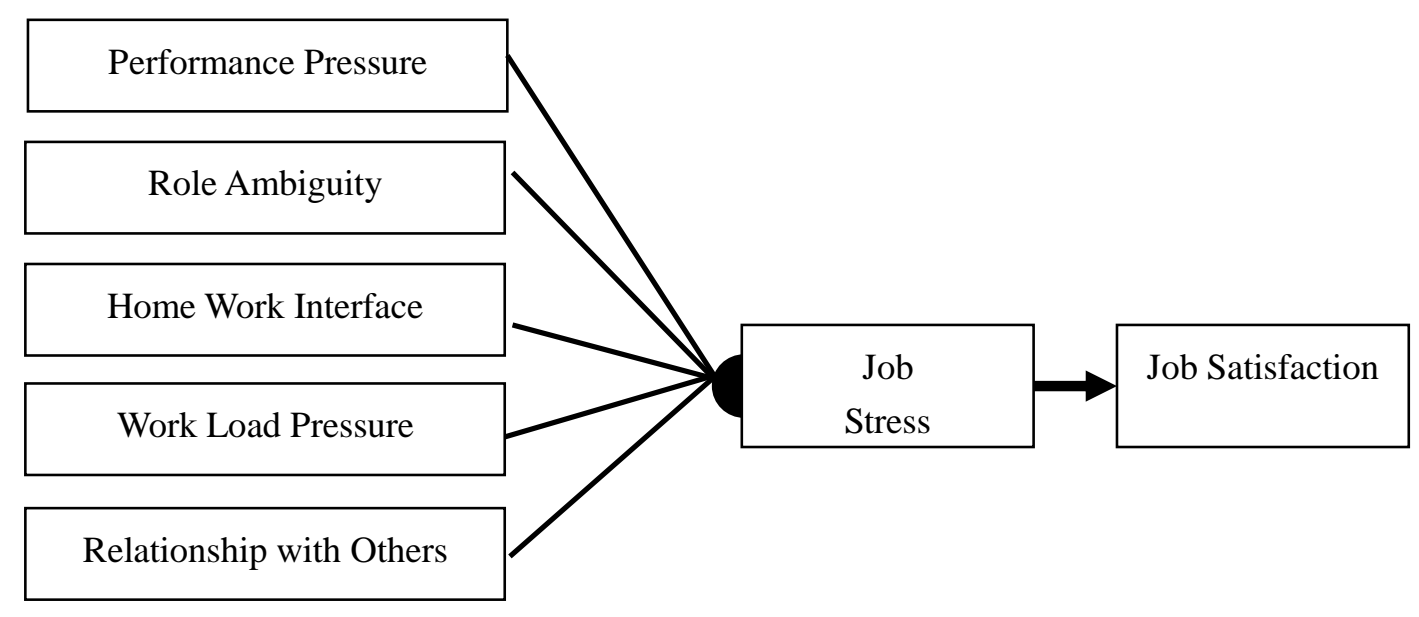

Figure 1: Diagram of the conceptual framework

Based on above discussions and theoretical framework, hypotheses are as follows:

Hypothesis 1: There is a positive relationship between performance pressure and job stress Hypothesis 2: There is a positive relationship between job role ambiguity and job stress Hypothesis 3: There is a positive relationship between home work interface and job stress Hypothesis 4: There is a positive relationship between workload pressure and job stress Hypothesis 5: There is a positive relationship between relationship with others and job stress Hypothesis 6: There is a negative relationship between job stress and job satisfaction 


\section{Methodology}

\subsection{Population and Sampling}

The population refers to the entire group of people, events, or things of interest that the researcher wishes to investigate (Uma \& Roger, 2009). Population for the current study includes air traffic controllers of Pakistan Civil Aviation Authority, as the target population working in four international airports - Karachi, Lahore, Islamabad, and Multan. These airports were randomly selected where $81 \%$ of total aircraft movements reported; $87 \%$ of total passengers travelled; and $95 \%$ of total cargo handled. Total population for the current study includes 670 air traffic controllers of Pakistan Civil Aviation Authority. 20\% of the total population was selected as sample. Detail of drawing sample from the whole population is given in table 1. Resultantly, author distributed 134 questionnaires to the respondents randomly by making lists and then selecting blindly. All the sample size consisted mix air traffic controllers from various shifts and locations. One hundred and twenty-two (122) air traffic controllers completed the questionnaire and the rest did not return it for unknown reasons. The response rate was $91 \%$ which is very much acceptable in social sciences research (Fowler, 1988). The participants were 5\% female and 95\% male with mean age of 42 years. More than $90 \%$ of them were married (115 respondent or $94.3 \%$ and 7 single) and rest were single. The sample represented 39 belonged to lower level management, 43 from middle level management, and 36 from senior level management. The average experience of the participants in their present profession was 15.3 years. Resultantly, it can be said that researcher has used the technique of cluster sampling for the purpose of drawing sample from the whole population.

Table 1 Population and Sample Statistics

\begin{tabular}{|c|c|c|c|}
\hline \multirow{2}{*}{$\begin{array}{l}\text { Name of Airport } \\
\text { (Population) }\end{array}$} & \multirow{2}{*}{$\begin{array}{l}\text { Total Air Traffic } \\
\text { Controllers } \\
\text { (Element) }\end{array}$} & \multicolumn{2}{|c|}{ Proportionate Sampling } \\
\hline & & $\begin{array}{l}\text { (20\% of the } \\
\text { elements) }\end{array}$ & $\begin{array}{l}\text { Questionnaire } \\
\text { Received }\end{array}$ \\
\hline Karachi & 325 & 65 & 64 \\
\hline Lahore & 280 & 56 & 51 \\
\hline Islamabad & 30 & 6 & 4 \\
\hline Multan & 35 & 7 & 3 \\
\hline Total & 670 & 134 & 122 \\
\hline
\end{tabular}

\subsection{Instrument Development}

As researcher has stated already that a study having almost same variables has been conducted earlier in some different situation with different sample and different country within different sector. Researcher has adopted the questionnaire developed by University of Newcastle's Engineering and Built Environment Research Ethics Committee (2005) for the current study. Total 92 questions were included in the questionnaire having different sections. First section of the questionnaire is related to demographics of the respondent, consisting of 8 questions, which covered variables like age, gender, education, marital status, job status, number of children, leave record and service record of respondents. For analysing all other 7 variables i.e. Job Satisfaction, Work Load Pressure, Role Ambiguity, Relationship with others, Performance Pressure, Home Work Interface and Job Stress 84 questions were included in the questionnaire (12 for each variable).

A five-point Likert Scale, in which I indicated 'strongly disagree, 2 indicated 'disagree', 3 
indicated neither agree nor disagree', 4 indicated 'agree', and 5 indicated 'strongly agree' is used for measuring the response. The main reason for this choice of all five job stressors was widely used in previous studies (University of Newcastle's Engineering and Built Environment Research Ethics Committee, 2005).

\section{Data Analysis}

Various statistical methods have been employed to compare the data collected from 122 respondents. These methods include cross-sectional analysis, descriptive analysis and regression analysis. Each method has used to analysis the relationship of different variables. The method of this study involved cross-sectional types of research methodology based on the guideline given by Hussey and Hussey (1997). The descriptive analysis was done to describe a set of factors in a situation that would make them easy to understand and interpret (Zikmund, 2000). The Statistical Package for Social Science (SPSS) Version 16.0 was used to analyze the data. To determine the reliability of the scale, the internal consistency was measured using Cronbach's Alpha value. Internal consistency describes estimates of reliability based on the average correlation among items within a test (Nunnally \& Bernstein, 1994). Both descriptive statistics (frequency, percentage, mean and standard deviation) and inferential statistics (Pearson correlation testing) were used for purposes of descriptive and co-relational testing respectively.

\subsection{Reliability}

Reliability of the items was verified by computing the Cronbach's alpha. Nunnally (1978) suggested that a minimum alpha of 0.6 sufficed for early stage of research.

Table 2: Reliability Statistics

\begin{tabular}{|l|l|}
\hline Variables & $\begin{array}{l}\text { Cronbach's } \\
\text { Alpha }\end{array}$ \\
\hline Performance Pressure & 0.656 \\
\hline Role Ambiguity & 0.651 \\
\hline Home Work Life & 0.738 \\
\hline Workload Pressure & 0.726 \\
\hline Relationship with Other & 0.657 \\
\hline Job Stress & 0.837 \\
\hline Job Satisfaction & 0.800 \\
\hline
\end{tabular}

Since all the variables have the alpha values greater than 0.6 the constructs were therefore deemed to have adequate reliability.

\subsection{Normality of Data and Multi-Collinearity}

This study consisted on 122 samples to check the normality assumption; we used a descriptive analysis where kurtosis and skewness are quit significant. Two major methods were utilized in order to determine the presence of multicollinearity among independent variables in this study. These methodologies involved calculation of both a Tolerance test and Variance Inflation Factor (VIF) (Kleinbaum et al, 1988). The results of these analyses are presented in Table 3. As can be seen from this data none of the tolerance levels is <or equal 
to .01; and all VIF values are well below 10. Thus, the measures selected for assessing independent variables in this study do not reach levels indicative of multicollinearity. The acceptable Durbin - Watson range is between 1.5 and 2.5. In this analysis Durbin - Watson value is 1.8 , which is between the acceptable ranges. It shows that there was no auto correlation problems in the data used in this research. Thus, the measures selected for assessing independent variables in this study do not reach levels indicative of multicollinearity.

Table 3: Collinearity Statistics

\begin{tabular}{|l|l|l|}
\hline & Tolerance & VIF \\
\hline Performance Pressure & 0.928 & 1.078 \\
\hline Role Ambiguity & 0.867 & 1.153 \\
\hline Home Work Interface & 0.964 & 1.037 \\
\hline Work Load Pressure & 0.940 & 1.064 \\
\hline Relationship With Others & 0.942 & 1.062 \\
\hline
\end{tabular}

\subsection{Hypotheses Testing}

Following the guidelines established by Hair et al. (1998), the six hypotheses were tested and the data were analyzed using multiple linear regression analysis. The regression coefficient of job stressors on job stress was estimated. The overall model is significant at the $1 \%$ level. Out of six hypotheses, three of them, performance pressure (+), role ambiguity (+), and homework interface $(+)$, were accepted at significant with $t$ value greater $>2$ and $\mathrm{P}=0$; while the variable 'workload pressure being negative (-) is rejected as its result shows that the relationship between workload pressure and job stress is negative but statistically insignificant with $\beta=-0.058$ ( $\mathrm{p}=0.28$ ). This negative relationship implies that the more the workload is given the air traffic controllers; the possibility of them to face job stress will be lesser. The result of hypothesis 5 (relationship with others) shows that there is statistically significant relationship between 'relationship with others' and 'job stress' and the value of coefficient is $\beta=-0.372$. The results of this study support the previous findings of Sauter, et al (1992) and Cox and Graffiths (1995) where t-value $=6.956$ (according to the rule of thumb if $|t| .2$; reject the $\mathrm{H}_{\circ}^{\circ}$ ). The result further indicates that the direction of association is negative in which it implies that the more the air traffic controllers friendly the lesser the job stress will be. Table 4 presents the results of the individual hypotheses being tested. 
Table 4: Regression Results

\begin{tabular}{|l|l|l|l|}
\hline Variables & $\begin{array}{l}\text { Standardized } \\
\text { Coefficients }\end{array}$ & t-value & P-Value \\
\hline & Beta & & \\
\hline (Constant) & & 7.072 & 0.00 \\
\hline Performance Pressure & 0.217 & 4.042 & 0.00 \\
\hline Role Ambiguity & 0.185 & 3.321 & 0.00 \\
\hline Home Work Interface & 0.215 & 4.073 & 0.00 \\
\hline Work Load Pressure & -0.058 & -1.090 & 0.28 \\
\hline Relationship With Others & -0.372 & -6.965 & 0.00 \\
\hline $\begin{array}{l}\text { Dependent Variable: Job } \\
\text { Stress }\end{array}$
\end{tabular}

\subsubsection{Hypothesis 1 (Accepted $|\mathbf{t}|>2)$}

The support of $\mathrm{H} 1$ (performance pressure) is in line with the results found by Chan et al. (2000). Multiple regression analysis shows relative advantage having $\beta=0.217(\rho=0.001)$ is the strongest predictor of job stress. Past literature has consistently shown that performance pressure is one of most significant and positive influence on job stress (Townley, 2000).

\subsubsection{Hypothesis 2 (Accepted $|t|>2$ )}

The Hypothesis 2 (role ambiguity) is accepted as the result of present study shows that the association between role ambiguity and job stress is significant with $\beta=0.185(\rho=0.001)$. The support for hypothesis reflects that more complex and rapid changes of organisation exist in the management or in the policies; the possibility of job stress will be higher.

\subsubsection{Hypothesis 3 (Accepted $|\mathbf{t}|>2$ )}

According to Lasky (1995), demands associated with family and finances can be a major source of 'extra-organizational' stress that can complicate, or precipitate, work-place stress. The multiple regression analysis shows that the association between homework interface and job stress is significant with $\beta=0.215(\rho=0.001)$. The result attests that the occurrence of stressors in the workplace either immediately following a period of chronic stress at home, or in conjunction with other major life stressors, is likely to have a marked impact on outcome (Russon \& Vitaliano, 1995). Furthermore, with the positive coefficient value, it could be concluded that the higher the problem in the home, the chances for the job stress will be greater.

\subsubsection{Hypothesis 4 (Rejected $|\mathbf{t}|<2)$}

Several studies have highlighted the deleterious consequences of high workloads or work overload. A study of work stress among professionals found that employees were most likely to experience work overload and that is one of the cause of work stress (Chan et al. (2000). The results of this study shows that the relationship between workload pressure and job stress is negative but statistically insignificant with $\beta=-0.058(\rho=0.28)$. This negative relationship implies that the more the more work overload is given the ATCO; the possibility of them to face of job stress will be lesser.

\subsubsection{Hypothesis 5 (Accepted $|t|>2$ )}

The results of this study support the previous findings of Sauter, Murphy and Hurrell (1992) 
Cox and Griffiths (1995), the $\mathrm{t}$-value $=-6.965$ (According to the rule of thumb if $|\mathrm{t}|>2$; reject the $\mathrm{H}_{0}$ ) which shows that there is statistically significant relationship exist between Relationship with others and Job Stress and the value of coefficient is $\beta=-0.372$ The result further indicate that the direction of association is negative in which it implies that the more the ATCO friendly the lesser the job stress will be.

\subsubsection{Hypothesis 6 (Accepted $|t|>2$ )}

To support hypothesis 6 we also used regression analysis to understand the effects of job stress versus job satisfaction. With job satisfaction as dependent variable and job stress as independent variable, a regression equation to represent this relationship is computed. Regress results are shown Tables 3 and 4 . Table 3 depicts the computer F-value and $\mathrm{R}$ square to understand the overall significance of the regression model. Research model yielding significant $\mathrm{p}$-values $(\mathrm{p}<0.01)$ and $\mathrm{R}$ square around 21 percent of the variance in job satisfaction was explained. Table 4 lists detailed data on the statistical coefficients of the regression model, the $\mathrm{t}$-value $=-8.065$ (According to the rule of thumb if $|\mathrm{t}|>2$; reject the $\mathrm{H}_{0}$ ) which shows that there is statistically significant relationship exist between Job Stress and Job Satisfaction and the value of coefficient is $\beta=-0.46$ The result further indicate that the direction of association is negative in which it implies that the more the ATCOs have Job Stress the lesser the Job Satisfaction will be. Therefore, hypothesis 6 is supported by the collected data.

Table 5: Summary of Regression Analysis Effects of Job Stress toward Job Satisfaction

\begin{tabular}{|l|l|l|l|l|}
\hline $\begin{array}{l}\text { Regression } \\
\text { Statistics }\end{array}$ & F-Value & P-Value & Adj-R2 & $\begin{array}{l}\text { Durbin-Watson } \\
\text { Test }\end{array}$ \\
\hline Values & 65.038 & $* * 0.00$ & 0.209 & 1.784 \\
\hline$* * \mathrm{p}<0.01$
\end{tabular}

Table 6: Relationship between Job Stress toward Job Satisfaction

\begin{tabular}{|c|c|c|c|c|}
\hline Variables & $\begin{array}{l}\text { Standardized Error } \\
\text { of Coefficient }\end{array}$ & t-value & $\begin{array}{l}\text { Standardized } \\
\text { Coefficient (beta) }\end{array}$ & $\begin{array}{c}\text { Regression } \\
\text { (p-value) }\end{array}$ \\
\hline Job stress & 0.057 & -8.065 & $-0.46(0.00)^{* *}$ & \\
\hline
\end{tabular}

\section{Conclusion}

The study was based on six hypotheses, which were tested and the data were analyzed using multiple linear regression analysis. Four of them, performance pressure $(+)$, role ambiguity $(+)$, and homework interface $(+)$, were accepted at significant with $t$ value greater $>2$ and $\mathrm{P}=0$; while the variables 'relationship with others (-)' and 'workload pressure (-)' were rejected as they were the predictors statistically different from zero and direct affect on job stress but statistically insignificant. The data demonstrates strong support for the hypothesis that there is an inverse relationship between job stress and job satisfaction. Our results agree with those of the studies conducted by Jamal (1984) and Hsiow-Ling (2004) showing the inverse stress performance relationship. Performance pressure, role ambiguity, home work interface have contributed to increase stress in air traffic controllers' job satisfaction; while work load and relationship with others remained insignificant. The workplace of Pakistan Civil Aviation Authority foster culturally friendly relationships; while workload pressure is not as much as 
compared with any developed country, therefore, such results might be different in other environment.

Reason being this that air traffic control area in aviation sector is more stressful than the rest of the areas. The major stress factors in air traffic controllers were performance pressures: when arousal is either too high or too low, performance declines and so does the job satisfaction; role ambiguity: when an air traffic controller has inadequate information about his/her work role results in job stress that affect job satisfaction; Home work interface: family and work are inter-related to the extent that experiences in one area affect the quality of life in the other. On the other hand work load and relationship with other remained insignificant contributors to work job stress among air traffic controllers. A possible explanation is that employees usually look up to their supervisors and if they do receive their support, they might feel that their work is appreciated and become more secure in regard to their job which might decrease their stress level and vice versa.

The results of the current study indicate that there is a negative relationship between job stress and job satisfaction. Those air traffic controllers who had high level of job stress had low job satisfaction.

\section{Limitations of Study}

Like other empirical studies, this study is not without its limitations. Our sample consisted of Pakistan may limit the generalization of the results. The study can be strengthened by increasing the sample size as the data analysis results and findings may vary substantially when the sample size is increased or decreased. As only limited and Pakistani workplace environment may not represent the whole region or international civil aviation authorities. Involvement of more aviation authorities of the world would create a more diffused results and findings. So the results are only applicable to the Pakistan Civil Aviation Authority. Lastly, more factors or variables can also be included in the Theoretical Framework as stress can be caused by many different aspects of the working environment.

\section{Practical Implications}

Sample size for the current study is consisted of the air traffic controllers of Pakistan Civil Aviation Authority. So the results are very much helpful for the same field. Practically speaking, if the results of the current study are applied to the CAA of Pakistan, it can cause a lot of betterment for the organization. Higher level management would be very much on ease if the middle and lower level management are satisfied with their job. Current study provides the endeavors for the organization that what are the drivers for the stress to be created in the organization which ultimately leads to the job dissatisfaction.

\section{Future Research}

With an increased sample size, a more detailed empirical study among independent variables and the variables that have multiple categories can be correlated and analyzed. Potential correlation between some of the independent variables (e.g. gender, race, education level, organization culture, impact of technology, organization climate, emotional demands of work and unclear work roles) need to be reported in a future study. 


\section{Acknowledgement}

It has been a challenge but enriching experience to complete this research paper. We wish to thank everyone who helped us complete this article. Without their continued efforts and support, we would have not been able to bring our work to a successful completion. Our big thanks to air traffic controllers (respondents) and airport services personnel of Pakistan Civil Aviation Authority who facilitated the survey. Our special thanks to Mr. Murtaza Ahmed, Manager Airside, and Mr. Rana Zaman Senior Air Traffic Controller who shared their views for providing the valuable qualitative information. 


\section{References}

Ahsan, N., Abdullah, Z., Fie, D., \& Alam, S. (2009). A study of job stress on job satisfaction among university staff in Malaysia: Empirical Study. European Journal of Social Science, 8(1), 121-131.

Alexandros-Stamatios G. A., Matilyn J.D., and Cary L.C., 2003. "Occupational Stress, Job satisfaction, and health state in male and female junior hospital doctors in Greece", Journal of Managerial Psychology, 18(6), pp. 592-621.

Amble, B. (2006, February 17). Asia worse hit by global stress epidemic. Retrieved November 2010, from Management Issues: http://www.management-issues.com/2006/8/24/research/asia-worse-hit-by-global-stre ss-epidemic.asp

Babjide, E. O., \& Akintay, I. (2011). Occupational Stress, Psychological Well Being and Workers' Behaviour in Manufacturing Industries in Wouth-West Nigeria. International Journal of Management and Innovation, Vol. 3(Issue 1).

Beehr, T.A. \& Newman, J.E, 1978. "Job Stress, Employee Health and Organizational Effectiveness: A Facet Analysis, Model and Literature Review", Personnel Psychology, 31, pp.665-669.

Beehr, T.A., Walsh, J.T., \& Taber, T.D. 1976. "Perceived situational moderators of the relationship between subjective role ambiguity and role strain', Journal of Applied Psychology, 61, pp.35-40.

Beehr, Terry A. (1995), Psychological Stress in the Workplace, London and New York.

Bergh, Z. \& Theron, A. (Eds.). (2000). Psychology in the work context. Oxford: Oxford University Press. P.480

Breaugh, J. A. \& Colihan, J. P. (1994). Measuring Facets of Job Ambiguity: Construct Validity Evidence. Journal of Applied Psychology, 79, 191 - 202.

Chan, K.B., Lai, G., Ko, Y.C. \& Boey K.W., 2000. "Work stress among six professional groups: the Singapore experience", Social Science Medicine, 50(10), pp.1415-1432.

Chan, K.B., Lai, G., Ko, Y.C. \& Boey K.W., 2000. "Work stress among six professional groups: the Singapore experience", Social Science Medicine, 50(10), pp.1415-1432.

Coleman J.C. 1976. Abnormal Psychology and Modern Life (Indian reprint), Taraporewalla, Bombay.

Cooper, C., U. Rout and B. Faragher. 1989. "Mental Health, Job Satisfaction, and Job Stress Among General Practitioners", B Medical Journal, 298, pp366-370.

Cooper, C.L., 1991. Stress in organizations. In M. Smith (Ed.). Analysing Organizational Behaviour. London: MacMillan.

Cordes, C.L., and Dougherty, T.W. 1993. "A review and integration of research on job burnout", Academy of Management Review, 18, pp.621-656.

Cotton, J., Vollrath, D., Froggatt, K., Lengnick-Hall, M., \& Jennings, K. (1988). Employee participation: Diverse forms and different outcomes. Academy of Management Review, 73: 103-112.

Cox, T and Griffiths, A (1995): "The nature and measurement of work stress: theory and practice" in J R Wilson and E N Coriett [ends] Evaluation of Human Work 2nd edtn., London, Taylor and Francis 
Cummins R.C. 1990. "Job stress and the buffering effort of supervisory support", Group and Organizational Studies, 15(1), pp.92-104.

Dyer, S., \& Quine, L. 1998. "Predictors of job satisfaction and burnout among the direct care staff of a community learning disability service", Journal of Applied Research in Intellectual Disabilities, 11 (4), pp.320-332.

Firth-Cozens, J. (2001). Medical Students Stress. Medical Education, 35, 6-7.

Fisher, C.D., \& Gitelson, R. 1983. "A meta-analysis of the correlated of the role conflict and ambiguity”, Journal of Applied Psychology, 68, pp.320-333. European Journal of Social Sciences - Volume 8, Number 1(2009) 130

Fisher, S. (1994). Stress in academic life: The mental assembly line. London: The Society for Research into Higher Education \& Open University Press, p.2

Fletcher, J.B., \& Payne, R. 198). "Stress and Work: A Review and a Theoretical Framework", Part 1, Personnel Review, 9, pp. 1-20.

Fowler, F. (1988). Survey Research Methods. New York: Sage Publication.

Gaillard, A., \& Streyvers, F. (1989). Sleep loss and susstained performance, In A. Coblentz (ed.) Vigilance and Performance. In Automatized system. the Netherlands: Kluwer Academic Publishers.

Ganster, D. (1989). Worker control and well-being: A review of research in the workplace, in Cooper, C. L. \& Robertson I. T. (Ed.). London: John Wiley and Sons.

Hackman, J. R., \& Oldham, G. R. (1975). Development of the job diagnostic survey. Journal of Applied Psychology, 60, 159-170.

Hair, J., Anderson, R., Tatham, R., \& Black, W. (1998). Multivariat Data Anaklysis (5th ed.). Upper Saddle River, NJ: Prentice Hall.

Hendy KC, Farrell PSE, East KP (2001) An information-processing model of operator stress and performance. In: Stress, workload, and fatigue: theory, research and practice, Hancock PA and Desmond PA (Eds.), 321-33, Lawrence Erlbaum, New Jersey.

Homburg, C. R., \& Stock. (2004). The link between salespeople's job satisfaction and customer satisfaction in a business-to-business context: a dyadic analysis. Journal of the Academy of Marketing Science, 32 (2) 144-158.

Hsiow-Ling, Liang-Chich, Kuo-Jen. Work stress \& job performance in the hi -tech industry: A closer view o f vocational education. World Transactions Engr Tech Edu 2004;3(1):147-50.

Hurrell JJ-Jr (2005) Organizational stress intervention. In: Handbook of work stress. Barling J, Kelloway EK and Frone MR (Eds.), 7-34, Sage Publications, Thousand Oaks, CA.

Hussey, J. and Hussey, R., 1997. Business Research, A practical Guide for Undergraduate and Postgraduate Students, Macmillan Press Ltd, London.

Igharia, Magid and Greenhaus, Jeffrey H. 1992. "Determinants of MIS Employees' turnover intentions: A Structural Equation Model", Communications of the ACM, 35(2), pp.34-49 [21] Jackson, S.E., \& Schuler, R.S. 1985. "A meta-analysis and conceptual critique of research on role ambiguity and role conflict in work settings", Organizational Behavior and Human Decision Processes, 36, pp.16-78.

Jackson, S.E., \& Schuler, R.S. 1985. "A meta-analysis and conceptual critique of research on role ambiguity and role conflict in work settings", Organizational Behavior and Human 
Decision Processes, 36, pp.16-78.

Jackson, S.E., \& Schuler, R.S. 1985. "A meta-analysis and conceptual critique of research on role ambiguity and role conflict in work settings", Organizational Behavior and Human Decision Processes, 36, pp.16-78.

Jamal M. Job Stress and job performance controversy: an empirical assessment. Organ Be have Human Perform 1984;33:1-21.

Kahn, R. L., Wolfe, D. M., Quinn, R. P., Snoek, J. D., \& Rosenthal, R. A. (1964). Occupational Stress: Studies in role conflict and ambiguity. New York: Wiley.

Kahn, R.L., \& Quinn, R.P. 1970. Role stress: A framework for analysis, In A. McLean (Ed.), Occupational mental health, New York: Wiley.

Kleinbaum, D. G., Kupper, L. L., and Muller, K. E. 1988. Applied Regression Analysis and Other Multivariate Medhods, Boston: PWS.

Koslowsky, M., Kluger, A., \& Reich, M. 1995. Commuting Stress: Causes, Effects, and Methods of Coping. Plenum, New York.

Landsbergis, P.A. 1988. "Occupational stress among health care workers: A test of the job demands - control model”, Journal of Organizational Behavior, 9, pp.217-239.

Lasky, R.G, 1995. Occupational stress: a disability management perspective. In D.E. Shrey \& M. Lacerete (Eds.). Principles and Practices of Disability Management in Industry, pp.370-409.

Lazarus RS, Folkman S (1984) Stress, appraisal and coping. Springer, New York.

Lee, J. \& Graham, A.V. (2001). Students' perception of medical school stress and their evaluation of wellness elective. Medical Education, 35, 652-659

Limbert, C. (2004). Psychological Well-Being and Job Satisfaction amongst Military Personnel on Unaccompanied Tours: The Impact of Perceived Social Support and Coping Strategies, Military Psychology: Lawrence Erlbaum Associates.

Loveman, G. W. (1998). Employee satisfaction, customer loyalty, and financial performance: Challenging the satisfaction mirror. International Journal of Service Research, 1 (1) 18-31.

Marilyn, M. H. (2003). "Stress in the workplace". Retrieved October 28, 2010, from daltonstate.edu: http://www.daltonstate.edu/faculty/mhelms/citizen/2003/Article\%2064.html

McGinty, R. H. (2007, January 8). Stress in the workplace: The easy way to beat stress and be happy. Retrieved November 3, 2010, from Digital Audion Books: http://www.digitalaudiobooks.co.uk/self-help-general/stress-in-the-workplace-the-eas y-way-to-beat-stress-and-be-happy-unabridged-audio-book_bk_summ_000003uk.asp $\mathrm{x}$

McGrath, J. E., "Stress and Behavior in Organizations," in M. D. Dunnette, ed., Handbook of Industrial and Organizational Psychology: Vol. 3, 2nd edition, Chicago: Rand McNally, 1976, pp. 1351-1395.

Melhuish, A.H. (1981). A doctor's role in educating managers about stress. In J. Marshall and C.L. Cooper (Eds.), Coping with stress at work: Case studies from industry, (pp. 3-40).

Muchinsky, P. 1997. Psychology applied to work: An introduction to industrial and organizational psychology (5th Ed.). Pacific Grove, CA: Brookes/Cole Publishers. 
Nassab, R. (2008). Factors Influencing Job Satisfaction amongst Plastic Surgical Trainees: Experience from a Regional Unit in the United Kingdom. European Journal of Plastic Surgery, 31(2), 55-58.

Naylor, J. C., Pritchard, R. D., \& Ilgen, D. R. (1980). A Theory of Behavior in Organizations. New York: Academic Press.

Nunnally J.C. 1978. Psychometric theory, New York: McGraw-Hill.

Nunnally, J. C., \& Bernstein, I. H. (1994). Psychometric Theory (3rd ed.). New York: McGraw-Hill.

Rizzo, J.R., House, R.J., Lirtzman, S.I. 1970, "Role conflict and ambiguity in complex organizations", Administrative Science Quarterly, 15(June), pp.150-63.

Russo, J., \& Vitaliano, P. 1995. "Life events as correlates of burden in spouse caregivers of persons with Alzheimers disease”, Experimental Ageing Research, 21, pp.273-294.

Sanders, A. F. (1983). Towards a Model for Stress and Human Performance. Acta Psychological, 53, 61-97.

Sanders, A. F., “Towards a Model for Stress and Human Performance,” ACTA Psychological, Vol. 53, 1983, pp. 61-97.

Sarantakos, S. 1996. Modern Families, South Yarra: MacMillan Education Australia Pty Ltd.

Sauter, S.L; Murphy, L.R. and Hurrell, JJ (1992) "Prevention of work-related psychological disorders: a national strategy proposed by NIOSH" in G Keita and S Sauter [ends] Work and Wel-Being: An Agenda For The 1990s, Washington DC, American Psychological Association

Schneider. B., Hanges, P.J., Smith, B., \& Salvaggio, A. N. (2003). Which comes first: Employee attitudes or organizational financial and market performance? Journal of Applied Psychology, 88, 836-51.

Scott, W. E., Jr., "Activation Theory and Task Design," Organizational Behavior and Human Performance, No. 1, 1966, pp. 3-30.

Selye, H. (1956). The Stress of Life. New York: McGraw-Hill.

Selye, Stress Without Distress, New York: JP Lippicott Company, 1975.

Sexton JB, Helmreich RL. (2000), Analyzing cockpit communications: the links between language, performance, error, and workload. Human Performance in Extreme Environments;5:63-8.

Sexton JB, Thomas EJ, Helmreich RL. (2000), Error, stress, and teamwork in medicine and aviation: cross sectional surveys. BMJ 2000;320:745-9.

Sharratt, A. (2003, March). Silver Linings. Benefits Canada, 27(3), 51.

Sheena J., Cary C., Sue C., Ian D., Paul T., Clare M. 2005. "The experience of work-related stress across occupations", Journal of Managerial Psychology, 20(2), pp. 178-187.

Sidek, M. N. (2002). Perkembangan Kerjaya: Teori dan Praktis. Serdang: Penerbit Universiti Putra Malaysia.

Silvestro, R. S. (2000). Applying the service-profit chain in a retail environment: Challenging the satisfaction mirror. International Journal of Service Industry Management, 11 (3) 244-268.

Smither, R. D. (1994). The Psychology of Work and Human Performance (2nd ed.). New York: Harper Collins College Publishers. 
Srivastava, A. K., and A. Krishna, "A Test of Inverted U Hypothesis of Stress Performance Relationship in the Industrial Context," Psychological Studies, Vol. 34, 1991, pp. 34-38.

Stamps, P.L., \& Piedmonte, E.B. 1986. Nurses and work satisfaction: An index for measurement. Ann Arbor, MI: Health Administration Press Perspectives.

Townley, G. 2000. "Long hours culture causing economy to suffer", Management Accounting, 78 (6), pp.3-5. European Journal of Social Sciences - Volume 8, Number 1 (2009) 131

Uma, S., \& Roger, B. (2009). Research Methods for Business - A Skill Building Approach, 5th Edition, p. 262. John Wiley \& Sons.

Ursprung, A.W. 1986. "Incidence and correlates of burnout in residential service settings", Rehabilitation Counseling Bulletin, 29, pp.225-239.

Van Sell, M., Brief, A.P., \& Schuler, R.S., 1981. Managing Job Stress, Little Brown \& Company, Boston, MA

Vinokur-Kaplan J.X. 1991. "Job Satisfaction among Social Workers in Public and Voluntary Child Welfare Agencies", Child Welfare, 155, pp. 81-91.

Wilkes, L., Beale, B., Hall, E., Rees, E., Watts, B., \& Denne, C. 1998. “Community nurses' descriptions of stress when caring in the home", International Journal of Palliative Nursing, 4 (1).

Williams, S. S., \& Wong, T. (1999). Mood and organizational citizenship behaviour: the effects positive affect on employee organizational citizenship behaviour intentions. Journal of Psychology, Vol. 133 (6) 656-66.

Williams, S., Pitre, R., \& Zainuba, M. (2000). Does mood influence organizational citizenship behaviour intentions? An experimental manipulation of affective state. Research and Practicve in Human Resource Management, Vol. 8 (2) 49-59.

Yerkes, R., and J. Dodson, "The Relation of Strength of Stimulus to Rapidity of Habit Formation," Journal of Comparative Neurology and Psychology, Vol. 18, 1908, pp. 459-482.

Yoon, M. H. (2003). Organizational citizenship behaviours and service quality as external effectiveness of contact employees. abs, 4.

Zikmund, W.G.2000, Exploring Marketing Research, 7th Edition, Dryden Press, Fort Worth Introduction

Zuzanek J, Beckers T (1999) Relationship between Time Pressure, Psychological Stress, Lifestyle, and Health: The Work-family Interface. http://www. lifestress.uwaterloo.ca/Introduction.htm. Accessed June 14, 2005 